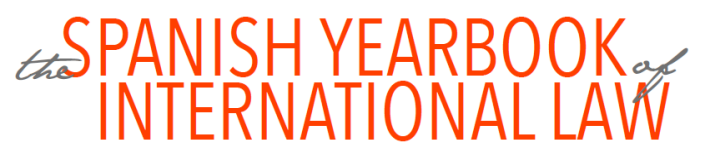

\title{
The Jus Gentium as Universal Order
}

\section{Antonio Truyol Serra*}

In a lecture given at this university 46 years ago, in June 1946, commemorating the $400^{\text {th }}$ anniversary of the death of Francisco de Vitoria and entitled 'Premisas filosóficas e históricas del totus orbis de Vitoria' (Philosophical and historical premises of Vitoria's totus orbis'), I began by noting, 'The notion of a totus orbis, a sort of world community of mankind, conceived of as a legal entity encompassing all States on the basis of natural law, is undeniably Francisco de Vitoria's greatest and most innovative conception. Without completely doing away with the idea of Christianity, an agreeable one in the Middle Ages, the guiding principle of which was the profession of a single religious faith, it nevertheless established itself as a linchpin of the system of international relations. Thereafter, it enabled the successive incorporation of non-Christian States into the international community. As a result of this idea, modern international law is universal in nature, and that is why Vitoria is rightly known as the founder of modern international law.'

Given the similarities between the subject of that lecture and the one I was asked to give for the part of this conference devoted to 'Salamanca and the Law of Nations', I could think of no better way to begin than by revisiting those words, despite the time that has elapsed since I first spoke them on no less solemn an occasion than the one that brings us together today. Because the idea of totus orbis, of the whole world, encapsulates, in Vitoria's own words, the understanding of the law of nations as a world order, as he devised it and as it was further developed by his followers at the University of Salamanca and even by those who, like Francisco Suárez, did not, strictly speaking, belong to the school associated with that city, but did, together with it, belong to the Spanish school of the law of nations or, as it is often called beyond our borders, $16^{\text {th }}$ - and $17^{\text {th }}$-century Spanish moral theology.

Vitoria's conception of the law of nations as a universal order had precedents and premises in theology and history, which the aforementioned lecture sought to elucidate. Naturally, I will not reiterate here what I said then, although certain references cannot be avoided. Instead, I will attempt to trace the genesis of these unavoidable doctrinal and factual precedents for Vitoria's work in the great Dominican's thought and to offer an overview thereof.

The fact that a legal order is international does not make it universal. An international legal order arises as soon as multiple, distinct, independent political societies maintain minimally stable relations based on the equality, in principle, of the parties. The exact number of societies (in modern times,

(1931-2003). Former Professor of International Relations, Universidad Complutense de Madrid. Member of the Institut de Droit International. This work was previously published in Spanish as 'El Derecho de gentes como orden universal', in A. Mangas Martín (coord.), La Escuela de Salamanca y el Derecho internacional en América. Del pasado al futuro (Salamanca, 1993) $17-25$. Unless otherwise indicated, all translations are the author's own.

'Prémisses théologiques et historiques du totus orbis de Vitoria', 72 La Ciencia Tomista (1947), at I23. 
States) that are involved is not, in and of itself, important. It will depend on the political composition of mankind in the given place and time and the network of relations established among its members. Needless to say, there was no global international legal order - nor could there have been - prior to the $16^{\text {th }}$ century, that is, the century of Vitoria, when the major discoveries and consequent expansion of the West - in two directions, with Europe's Atlantic states crossing the ocean and the Russians moving overland into northern Asia- marked the start of the unification into a single global system of the various partial international legal orders that had existed to date, which had functioned independently, either wholly cut off from each other or just barely interconnected.

In fact, as Baron Korff would point out in the first session of courses given at the International Law Academy in the Hague in the I920s addressing those who held that international law was a modern creation, "international law is as old as civilization itself and is a necessary and inevitable consequence of all civilizations". For as soon as a culture achieves a certain level of civilization, that is, a State of some importance, it simultaneously begins to engage in relations with the world beyond its borders, which soon take on the form of a system of institutions. ${ }^{2}$ I share this opinion, which was further corroborated by P. Vinogradoff, who, also in 1923, observed that characteristic features of international law can be found at all levels of civilization. ${ }^{3}$

In its infancy, this international law was merely regional, with a limited geographical scope of validity, whether it was confined to a single cultural area (e.g. as in ancient India or the Greek city states) or to regions that were home to multiple cultural areas (e.g. the ancient eastern Mediterranean or the Christian-Muslim Mediterranean of the Middle Ages). Over time, these hubs of international law, which started off small and relatively isolated, began to expand and open themselves up, to communicate with each other and fight for supremacy in a process that would not culminate until the $19^{\text {th }}$ or even, in view of the aftermath of colonization and decolonization, the second half of the $20^{\text {th }}$ century.

This process followed naturally from the achievement of certain milestones of civilization, including trade, spurred on by the desire to exchange goods as the needs for a better life grew, as the respective societies' began to perceive their interdependence, and as the available means of both cooperation and conflict increased. However, what might be called the logic of security, inherent to all legal orders, and, thus, the international legal order, too, was also moving in this direction. While this state of things guaranteed the parties a relative degree of security, by regulating recourse to war and, insofar as possible, limiting the damage it caused, it nevertheless left them vulnerable to the emergence of disruptive, when not downright devastating, powers from outside the international society in question (hence, the Mongol invasions in Asia Minor and Eastern Europe, not to mention those of the 'Peoples of the Sea', which, beginning in I200 BC, broke up the 'concert of empires' that had, for two and a half centuries, established and maintained political and economic balance in the ancient Eastern Mediterranean, or the arrival of Western powers in $16^{\text {th }}$-century India and $19^{\text {th }}$-century China and Japan, which, in both cases, forced those countries to open themselves up to world trade). No

'Introduction á l'histoire du droit international', I RCADI (I923), at 5, 2I.

3 'Historical Types of International Law', Bibliotheca Visseriana, Lugduni Batavorum, I, 1923. 
international order can guarantee all possible relative security unless it includes all the actors on the international stage, that is, unless it is global.

Hence, the trend towards universality was latent in all international societies. This trend could already be found in each regional international-political 'world', in the incipient international legal systems of antiquity. Only, this universalist calling, both then and (lest we forget) well into modern times, was taken up by the very empires that considered themselves 'worlds' unto themselves and that justified their own existence, when they bothered to do so at all, on the grounds of the peace they brought. It is common knowledge that, in ancient times, their land of choice was Mesopotamia and the so-called Fertile Crescent. The succession of empires that ruled it over the millennia merely underscores the futility of their efforts, which ultimately consisted of little more than accumulating a dominant or hegemonic power. Certainly some empires, such as the Chinese Empire, or the 'Middle' or 'Central Kingdom' as it called itself, which overcame countless difficulties to last until I9I2, the Persian Achaemenid Empire $\left(7^{\text {th }}-6^{\text {th }}\right.$ centuries BC), and the Roman Empire have all gone down in history as peacemakers, having taken this universalist approach to its zenith. Indeed, the Pax Romana, whose praises were already being sung in antiquity by eloquent Pagan and Christian panegyrists, is the very embodiment of this peacekeeping action, just as the peace imposed by the Spanish and British in the Americas and the general colonial peace imposed in Africa and Asia would be centuries later.

However, imperial solutions to the problem of international order are notoriously flawed, as history has shown time and again from its earliest beginnings. One hardly need be reminded that no empire, no matter what it may have claimed, has ever been, nor could be, universal. Indeed, no imperium mundi has ever been universal even within its own partial or regional 'world', as it were, and all, at the very least, have had their own more or less threatening 'barbarians'. Moreover, one must consider the price of the peace they brought (when they managed to bring it at all), based on the domination, early on, of the conquered peoples, a price that also included internal power struggles among the dominant people themselves, wars with rival empires, which raised the level of violence even further, and uprisings and rebellions of their subjects. This is in addition to the mass destruction wrought on the path to becoming an empire, which, in the aforementioned historical memory, is associated with that epitome of this legacy of terror, the memory of Tamerlane's Mongols and the piles of decapitated heads they stacked at the gates of the smouldering cities that had dared to resist them.

Of course, empires are not solely responsible for the violence of international relations. Unfortunately, libido dominandi is the common lot of all men, who need to be protected from a power that, if left unchecked, will most often end up imposing itself, especially when its fortification seems to be legitimized by the threat of competing powers. At the international level, in the absence of a higher authority recognized as such, this power has historically been limited by alliances of the weak, in search of balance. However, the fact that a group is small or weak does not guarantee that it will show moderation towards even smaller groups, as history, once again, can attest. All too often it is the anarchy of the small that has led the large to theoretically (and occasionally actually) unite. 
Modern empires, after Charles V, did not come as close as their predecessors did to being 'universal monarchies' in a world that, as already noted, was in the process of expanding. Their sheer numbers pitted them against one other so that, ultimately, they were no more than a handful of States with greater than average power locked in a struggle for hegemony.

Aside from these historical considerations, the notions of empire and universality make for uneasy bedfellows in that empire is inevitably based on the predominance of a specific people (even if this predominance is beneficial for the rest and they ultimately accept it), whereas universality implies a moral equality. In terms of people, universality is all humanity. In this regard, the ancient imperialisms relied on religions that might be called 'ethnic', specific to each race, city, kingdom or empire, each with its own protecting gods, and each obscuring the notion of a global community of individuals and peoples.

This idea made inroads, in the Ancient East, with the advent of the universalist religions and philosophies: Buddhism, Chinese humanism, Zoroastrianism and Hebrew prophecy. In ancient Greece and Rome, Stoic philosophy affirmed the unity of bumanitas, of the bumanum genus, included in the civitas maxima of men and gods under the rule of right reason that engenders a natural law common to all. This community is based on the moral equality of men, whose dignity derives from their participation in universal reason and demands mutual love (pbilantbropia), culminating in Seneca's 'bomo, sacra res bomini'. In its purely human dimension, the Stoic civitas maxima nevertheless takes the form of a cosmopolis, whose abstract nature, except in middle Stoicism (Panaetius, Posidonius), underestimated the intermediate reality of peoples.

Christianity gave full meaning to the unity of humanity and the equality and dignity of men, created, as they were, 'in the image and likeness of God'. All men had a common origin and a common heavenly destination, and while all may have sinned in Adam, all would also be redeemed by Christ; however, they were also divided into nations, peoples and villages, the reality of which was recognized as such, but transcended through charity. St. Paul put it most powerfully, when he described this transcendent equality thusly: 'There is neither Jew nor Gentile, there is neither slave nor free man, there is no male or female, for you are all one in Christ Jesus' (Galatians, 3:28). As for the villages, peoples and nations of the world, their place was established by St. Augustine in a classic passage from The City of God containing his reflections on the Roman Empire, which was clearly on the decline. Although he acknowledged the benefits that the peace imposed by the empire had yielded in terms of the co-existence of its constituent peoples and, especially, the spread of Christianity, the Bishop of Hippo did not believe that the empire's continued existence was necessary for a better world order. Rather than a universal empire, which would nevertheless be dominant, he preferred a great many 'kingdoms of nations', just as in the city there are a great many houses of citizens ('et ita essent in mundo regna plurima gentium, ut sunt in urbe domus plurimae civium', Book 4, Ch. I5). In his view, the unity of the higher purpose that compelled the heavenly city in its sojourns on earth cared naught for the diversity of laws, customs and institutions ('non curans quid-quid in moribus, legibus, institutisque') by which earthly peace was broken or kept, but rather preserved and adopted them all, no matter how they might differ among different nations ('diversum in diversis nationibus'), so long as they were intended to achieve one and the same end, namely, earthly peace (Book 19, Ch. 17). 
In addition to this notion of a humanity divided, in the natural realm, into people, peoples and nations living side by side, St. Augustine made another important contribution to the overwhelming issue of war at a time when, with the Roman Empire teetering on the brink of collapse, war, which the central authorities had excised from the heart of the empire, was steadily proliferating along its borders as a result of its attempts to defend them against invaders and, later, too, among the kingdoms that these invaders themselves established in various parts of the Western Empire. In keeping with a Ciceronian precedent, St. Augustine, rejecting the absolute pacifism of Tertullian and certain sects, held that the use of arms and war could be licit, provided it was justified, that is, provided it was undertaken solely to right a wrong. War is only legitimate when it is the only means of addressing an injustice between people, peoples or nations, and only the authorities should resort to it, on the condition that they limit themselves strictly to what is absolutely necessary and act only with the right intentions. St. Thomas and the jurist-theologians of the Spanish Siglo de Oro would simply adapt these principles to the new political and military conditions of their time.

As is well known, St. Augustine wrote The City of God in Hippo, while the city was under siege by Vandals. Once the Western Empire had fallen to the Germanic invaders in the north and, shortly thereafter (in a more decisive event with greater historical and spiritual repercussions) to the Arabs, and following the conversion of the Germano-Romanic, Germanic and Slavic kingdoms to Christianity, there arose from its ruins two international-legal complexes: one Christian and one Islamic (the latter representing the far western reach of a much broader cultural and religious reality that stretched to Central and Southeast Asia). Following the East-West Schism of ro48, Christianity was split in two: on the one hand, a western, Latin and Catholic Christianity (Roman); on the other, an eastern, Greek and 'orthodox' one (Byzantine). Although war was ever present between them, they were also open to heavy trade relations, a fact that gave rise to a type of intercultural international law involving, among Christians and Muslims, special clauses (regulating matters such as the reduction of prisoners of war to slavery or prohibitions on the export of certain items deemed likely to increase military power). Although once the Western Empire had been restored (first by Charlemagne and then by Otto I), both entities presented themselves as imperial structures, in reality they were more or less hierarchical international communities. With the fall of Constantinople (1453), part of the Byzantine community was absorbed by Islam, while the other part was eventually incorporated into the Western community, albeit retaining certain peculiarities.

The monotheistic foundation shared by the two monopoly religions of the Mediterranean facilitated such relations, although, for the Muslims, the peace formally consisted of a series of truces of varying duration. A decisive step in the consolidation of this intercultural legal order was St. Thomas Aquinas's reception of Aristotelian and Stoic natural law - a reception, it bears mentioning, facilitated by the reception of Aristotelianism in Arab translations, which, in turn, had been translated into Latin, especially in Toledo. The Thomasian synthesis of Aristotelianism and Christianity, similar to that previously undertaken by Muslim thinkers between Neo-Platonism, Aristotelianism and Islam, gave rise to a jusnaturalism, which, while it had precedents in patristics and St. Augustine, had much broader implications. The clear distinction between the realms of faith and reason, theology and philosophy, positive divine law and natural law, allowed the Angelic Doctor to reject earlier confusion 
between spiritual and temporal power, establish both public and private power and dominion in natural law, and, with a view to making them just, apply the same requirements to wars between Christians and infidels as were applied to wars among Christians, thereby establishing the legal equality of the two groups. He likewise attributed the authority to conduct a just war to kings, princes and republics (in the traditional sense of the term), which, in fact, had no superiors. In doing all this, he enabled an international legal order valid for all human societies, that is, an international legal order that was universal.

This notion was Vitoria's starting point at a time when, due to the discovery of the New World, the idea of humanity was proving to be much more complex, much richer anthropologically, culturally and politically speaking, than what had previously been thought based on the known societies of the Old World. It was a time when the positive-law categories then current in Western Christendom were forced to give way to those of a natural law faced with societies that had evolved beyond the bounds of general history. In other words, the idea of universality, which had already been enriched and made much more concrete through intercultural contact, nevertheless proved to be insufficient, and, in any case, room needed to be found in it for the various peoples who had undeniably joined in the global life of a planet whose true dimensions were only just then being glimpsed for the first time.

In short, the contribution of Vitoria, and, through him, of the School of Salamanca, to the law of nations essentially consisted of the application of general principles of Christian moral and natural law, a legacy of ancient and mediaeval thought, to his own times, marked as they were by profound and rapid changes.

One such change, following the crisis of Christianity in the $14^{\text {th }}$ and $15^{\text {th }}$ centuries, was the advent of the modern State, which, by virtue of its sovereignty, recognized no superior authority. Indeed, it is no coincidence that it was in this period that the new sense of the word 'State' first appeared, to designate the new political society that emerged from that crisis, as well as the term 'sovereignty', to describe the new entity's distinctive independence from all higher powers. Significantly, both the conceptual and lexical innovations occurred first in the vernacular languages (through the Italian 'lo Stato'), which had more room for new coinages than the traditional Latin terminology (Respublica, Civitas, Regnum; suprema potestas, summa potestas), which would be retained by those who continued to write their works in the language of Latium. Another change, more directly related to the topic at hand, was the start of what has elsewhere been called 'the expansion of international society'. ${ }^{4}$

Vitoria is known to have approached issues of the law of nations in terms of their systematic connection to those of political and ecclesiastical law. He thus discussed civil and ecclesiastical public law, the law of nations in peace and the law of nations at war in six lectures, given over the course of a decade, which can be subdivided, although not completely dissociated from one another, into two groups of three. The order in which they were given is, in itself, indicative of their epistemological purpose. First, he examined the issue of civil power (De potestate civili, 1528), followed by the power of the church (De potestate Ecclesiae prior and De potestate Ecclesiae posterior, 1532) and then, with regard

\footnotetext{
4 'L'expansion de la société internationale aux XIXe et XXe siècles', II6 RCADI (I965-III); and La Sociedad internacional (5 ${ }^{\text {th }}$ ed., Madrid, Alianza Editorial, 1985) (Part One).
} 
to the latter, the power of the pope and the council (De potestate papae et concilii, 1534). Once he had defined power in these two realms, he considered the law of international society in peace (De Indis recenter inventis relectio prior, 1539) and at war (De Indis, sive de iure belli bispanorum in barbaros, relectio posterior, better known as De jure belli, the same year). That the first and final two lectures in the series form a whole is clear from the fact that some of the major texts of Vitoria's doctrine of the law of nations can be found, as we will see, in his lecture on civil power. The direct relationship between the other three is clear. No less clear is the fact that they are united by a common thread, as complementary pieces of a public law system, which begins by distinguishing between temporal power and spiritual power before proceeding to analyse the role each one plays in international society and the use of force therein.

Like St. Thomas Aquinas, whose work he expressly drew on, Vitoria regarded political society, the respublica, as an institution of natural law, which operated independently in the sphere of the temporal purpose of man, while the Church was the product of positive divine law, oriented towards its spiritual purpose, with indirect power in temporal matters only to the extent that spiritual matters were at stake. The respublica arose from man's natural sociability, which, according to Vitoria (citing Aristotle, the Stoics and Cicero), surpasses the realm of family and other associations in terms of the complexity of the needs it makes it possible to meet. Unlike this 'perfect society', it is thus endowed with potestas publica, that is, with 'the faculty, authority or right to govern the civil republic' (De potestate civili, No. Io).

However, Vitoria did not consider political society, the respublica, in isolation as an ultimate political reality, but rather integrated it into his comprehensive world view. The secret of Vitoria's universal and lasting success has rightly been attributed to this sub specie orbis point of view, or, to quote Alois Dempf, to 'his grand political idea of the orbis, the community of peoples of all the world' in 'the planetary breadth of his political horizon, which can never again be surpassed, as it encompasses all the States of the world as a natural unit.'s Under natural law, all peoples are called upon to form what today we call States and to freely shape their destiny. However, the different peoples so formed find themselves joined to each other by their common human nature. The lineage of men forms a unit, the legal entity of the world (Orbis). Of course, the Vitorian world was not a super-State like Dante's universal monarchy, nor was it a civitas maxima in the Stoic style, like that described above, but rather a family of peoples as conceived of by St. Augustine. It was a community of both States and men. Hence, Vitoria rejected the universal jurisdiction of the Emperor, including de jure jurisdiction, as Bartolus asserted, going on to note that, in fact, there were plenty of kingdoms, republics and cities that were not under his control. The Emperor was not lord of the world by natural law, for under natural law political power appertains to each republic, kingdom or city; nor was he lord of it by positive law, as had historically been claimed; indeed, only if he were to be chosen as such by all the world could he be so.

La Filosofía cristiana del Estado en España, translation and introductory study by José $\mathrm{M}^{\mathrm{a}}$ Rodríguez Paniagua, (Madrid, Rialp, 196I), at 86-87. 
The international community is thus the result of man's natural sociability, which does not stop at the borders of his people, city or kingdom, but rather extends to the entire human race. His legal contract (ubi societas, ibi jus) is jus gentium, the law of nations', which Vitoria understood to have a dual meaning: first, as the universal law of all mankind (jus gentium as such), in the Roman tradition, and, second, as a law of towns, cities and kingdoms, of peoples, in their reciprocal relationships, a jus inter gentes that Suárez, in a Copernican twist of terminology, would transform into the law of nations in its own right.

The law of nations was, for Vitoria, part of natural law; however, human will, whether express or tacit, moreover gave rise to a positive law of nations, because the whole world (totus orbis), which, in a certain way (aliquo modo), forms a single republic (una respublica), has the power to pass just laws that are suitable for all; and no kingdom (or State) may consider itself less subject to the law of nations, 'as it derives from the authority of the whole world' (De potestate civili, 2I).

A consequence of the natural-law foundations of political society and temporal power, of the idea of the world and of a natural and positive law of nations of a universal scope, is the full recognition of the international legal personality of non-Christian political communities and their legal equality. 'Among the pagans, there is complete temporal and civil authority' (De potestate Ecclesiae prior, $\mathrm{r}: 8$ ), since 'infidelity does not destroy natural or positive human law' (De Indis, I:7); therefore, the barbarians of the New World, before the Spaniards' arrival, were its genuine masters, both publicly and privately (De Indis, I:24).

Separately, there is a natural law of society and communication (jus naturalis societatis et communicationis), from which one may not be excluded without just cause (De Indis, de titulis legitimis, I-3). Also, the principle of common good applies to the world as such, as its requirements are greater than those for the good of the parties. Hence, 'as a republic is part of the entire world, and a Christian province is primarily part of the republic as a whole, were war to be useful to a province or even to a republic yet harmful to the world or Christianity', Vitoria argued, 'it would be unjust for that very reason' (De potestate civili, $\mathrm{13}$ ).

The potential of the principle of the common good of the whole world, superior to the common good of the respective States, based on communication involving solidarity and reciprocity, is clear: this principle is called upon to act as a factor of distributive justice, or even of social justice (in the current sense of the term), among human collectives without distinction and among the members thereof. This statement is not intended to mark a departure from the horizon of Vitorian thought; on the contrary, this aspect thereof has rightly been related to current notions such as the 'common heritage of mankind'.

The main merit of Vitoria's notion of totus orbis, like Kant's conception, two and a half centuries later, of civitas gentium in his treatise on perpetual peace, is that it showed that the law of nations, or international law, only makes complete sense and can only fulfil its role as organizer and peacemaker if it is worldwide in scope.

Vitoria's totus orbis, like Kant's civitas gentium, is an idea that strives to inform reality. Whether or not it manages to do so will depend on the willingness of successive generations to search for a 
peaceful order that is also just, something that can only occur if it encompasses all mankind, and their determination to achieve something that, at this point in history, concerns us all without exception. 